\title{
Eighth-year response of Douglas-fir seedlings to area of weed control and herbaceous versus woody weed control
}

\author{
Robin RoSE*, Lee RoSNER \\ Department of Forest Science, Oregon State University, 321 Richardson Hall, Corvallis, OR 97331-5752, USA
}

(Received 21 July 2004; accepted 28 January 2005)

\begin{abstract}
Coastal Douglas-fir growth response to eight experimental weed control treatments has been followed for eight years since planting at two western Oregon sites. Treatments included six areas of weed control around individual trees $-0.0 \mathrm{~m}^{2}, 0.375 \mathrm{~m}^{2}, 1.49 \mathrm{~m}^{2}, 3.35 \mathrm{~m}^{2}$, $5.95 \mathrm{~m}^{2}$, and $9.63 \mathrm{~m}^{2}$ (total vegetation control [TVC]) - control of herbaceous competition only or control of woody competition only. Herbaceous vegetation control treatments were maintained for the first two years after planting, while woody vegetation control treatments were maintained for three years. The greatest gain in Douglas-fir growth from increasing the area of control was observed between the $0.0 \mathrm{~m}^{2}$ and the $0.375 \mathrm{~m}^{2}$ treatments. Growth continued to increase, however, with increasing area of control out to complete weed control. The $5.95 \mathrm{~m}^{2}$ and $9.63 \mathrm{~m}^{2}$ treatments increased eighth-year individual-tree volume relative to the check treatment by $260 \%\left(20.9 \mathrm{dm}^{3}\right) \mathrm{and}_{307 \%}\left(24.7 \mathrm{dm}^{3}\right)$, respectively. While herbaceous control increased growth at both sites, woody control affected growth only at the site having the hardwood component with greater height growth potential. Growth differences among treatments eight years after planting are discussed in terms of distance to competition and shifting dominance from herbaceous to woody vegetation over time.
\end{abstract}

vegetation management / herbaceous competition / woody competition / area of weed control / herbicides

\begin{abstract}
Résumé - Impact de la surface désherbée et d'un contrôle de la végétation herbacée ou de la végétation ligneuse sur la croissance de jeunes sapins de Douglas âgés de huit ans. La réponse en termes de croissance de plants de Douglas verts huit ans après plusieurs modalités de contrôle de la végétation adventice a été étudiée dans deux sites de l'ouest de l'Oregon. Les traitements comprennent 6 surfaces de contrôle des mauvaises herbes autour d'arbres individuels $-0,0 \mathrm{~m}^{2}, 0,375 \mathrm{~m}^{2}, 1,49 \mathrm{~m}^{2}, 3,35 \mathrm{~m}^{2}, 5,95 \mathrm{~m}^{2}$ et 9,63 $\mathrm{m}^{2}$ (contrôle total de la végétation (TVC)) - contrôle de la compétition herbacée seulement ou contrôle de la végétation ligneuse. Les traitements de contrôle de la végétation herbacée ont été maintenus les 2 premières années après plantation tandis que les traitements de contrôle de la végétation ligneuse ont été maintenus 3 ans. Le plus grand gain de croissance du Douglas avec l'augmentation de la surface de contrôle a été observé entre le traitement $0,0 \mathrm{~m}^{2}$ et $3,75 \mathrm{~m}^{2}$. Toutefois la croissance continue à augmenter avec l'accroissement de la surface de contrôle en dehors d'un contrôle total des mauvaises herbes. Les traitements $5,95 \mathrm{~m}^{2}$ et $9,63 \mathrm{~m}^{2}$ présentent après 8 années un accroissement relatif de volume individuel d'un arbre de $260 \%\left(20,9 \mathrm{dm}{ }^{2}\right)$ et $307 \%\left(24,7 \mathrm{dm}^{2}\right)$. Alors que le contrôle de la végétation herbacée augmente la croissance dans les deux sites d'étude, le contrôle de la végétation ligneuse influence la croissance uniquement dans le site qui a une composante d'espèces de feuillus ayant un fort potentiel de croissance en hauteur. Les différences de croissance parmi les traitements 8 années après la plantation sont discutés en termes de distance de la compétition et de modification dans le temps de la compétition des herbacées par rapport à la végétation ligneuse.
\end{abstract}

gestion de la végétation / compétition herbacée / compétition ligneuse / surface de contrôle des mauvaises herbes / herbicides

\section{INTRODUCTION}

Both the growth form of competing vegetation (herbaceous versus woody) and its distance from the crop tree influence competitive effects on seedling establishment in forest plantations. In contrast to competition indices and models that have focused more on woody cover as a predictor of Douglas-fir (Pseudotsuga menziesii var. menziesii [Mirbel] Franco) growth $[1,12]$, numerous studies have demonstrated the importance of herbaceous vegetation as a competitor to Douglas-fir $[6,11,19$, $20,24]$. Few studies have reported the relative effects of both herbaceous and woody competition on Douglas-fir [6, 13, 30,
33]. Rose et al. [25] is the only published study comparing Douglas-fir growth responses following complete control of woody vegetation (without control of herbaceous vegetation) to complete control of herbaceous vegetation (without control of woody vegetation) in a developing stand. Eighth-year results from that study are presented here.

Herbaceous and woody competitors differ both in their mechanisms of interference as well as their duration of influence. Whereas light is a primary resource sequestered by tallgrowing woody competitors $[4,12,14,22]$, herbaceous cover competes with tree seedlings primarily for below-ground resources - water and nutrients [28]. In studies examining the

\footnotetext{
* Corresponding author: robin.rose@ oregonstate.edu
} 
relative importance of woody and herbaceous competition on seedling establishment, maximum cover and competitive influence is typically earlier for herbaceous competition and later and more long-lasting for woody competition. Miller et al. [18] found that across 13 southeastern United States loblolly pine plantations, woody cover in untreated plots has gradually risen across the first 15 years of the study, whereas herbaceous cover reached a peak by year two and began to drop in all cases by year seven - earlier at some sites. Harrington et al. [13] found that Douglas-fir basal-area growth following a series of weed control treatments was significantly limited by herbaceous cover in years 2 and 3, shrub cover in years 3 through 5 and tree cover in years 3 through 10 . These results underscore the fact that studies comparing the effects of woody versus herbaceous control must be carried out long-term in order to capture the effects of changing dynamics in vegetation communities resulting from early treatments.

Competition models typically use distance modifiers or a fixed-radius zone of influence to modify competitive effects [1, $3,7,8,23,29,30]$. Zone size varies depending on the model and species and typically ranges from 1 to $20 \mathrm{~m}^{2}$. A more direct approach in assessing the zone of influence of competition is to measure the growth response resulting from tree-centered spot herbicide treatments of varying areas. Results from this approach have varied depending on the tree species and site, often with larger than expected zones of influence. Jaramillo [15] found Douglas-fir diameter growth over the first three years of establishment increased with increases in the area of control up to $4.5 \mathrm{~m}^{2}$ and $18.1 \mathrm{~m}^{2}$ at two southwest Oregon sites. Oester et al. [21] observed that ponderosa pine (Pinus ponderosa Dougl. ex Laws.) seedlings receiving a single broadcast release treatment after planting had more than double the fifthyear stem volume of seedlings receiving a single $2.3 \mathrm{~m}^{2}$ spot treatment, suggesting that much larger spot treatments would have been effective. At two southern United States sites diameter growth of loblolly pine increased with area of control up to $18.1 \mathrm{~m}^{2}$ (complete broadcast control) [9]. Richardson et al. [23] found that the optimal area of spot weed control in radiata pine (Pinus radiata D. Don) varied depending on the productivity of the site, but on the more productive of two sites diameter growth increased with increasing spot size up to complete broadcast control ( $>1.5$ m radius).

In this paper we present growth results from an eight-yearold study evaluating six areas of tree-centered weed control as well as total herbaceous control for two years and total woody control for three years. Third-year results have been previously presented [25]. The goal of the study is to test the null hypotheses that large areas of tree-centered vegetation control (up to $9.6 \mathrm{~m}^{2}$ ) will not improve Douglas-fir growth compared to smaller areas of control, and that there will be no difference in tree growth between herbaceous-only and woody-only treatments. After three years the effect of area of control on growth was highly site-dependent, peaking at $4 \mathrm{~m}^{2}, 6 \mathrm{~m}^{2}$ or continuing to increase beyond $9 \mathrm{~m}^{2}$. Herbaceous control resulted in larger stem diameters, heights and stem volumes than woody control at two of three sites. We suspect that this pattern of response will have changed after eight years due to shifts in the competitiveness of resulting plant communities during and after canopy closure.

\section{MATERIALS AND METHODS}

\subsection{Study sites}

The two study sites are in western Oregon near the towns of Summit, and Marcola. The Summit site is located on hummocky ground in the central region of the Oregon Coast Range $32 \mathrm{~km}$ west of Corvallis at an approximate elevation of $234 \mathrm{~m}$. Slopes range from $2 \%$ to $20 \%$, and aspect varies dramatically, depending on plot location. The site is on the Apt soil series, which consists of deep, well-drained soils that formed in colluvium weathered from sedimentary rock. Site index is $41 \mathrm{~m}$ (base age $=50$ y) [17]. Rainfall averages $1726 \mathrm{~mm}$ per year. Before harvest, this hardwood conversion site was dominated by bigleaf maple (Acer macrophyllum Pursh), alder (Alnus rubra Bong.), and cherry (Prunus emarginata Dougl.). After harvest, which took place in the summer of 1992, slash was raked off and the ground was scarified with ripper blades. The site was also subsoiled with a winged blade that ripped the soil behind a D-6 Caterpillar tractor to a depth of approximately $60 \mathrm{~cm}$, laterally fracturing it and reducing its bulk density. Douglas-fir $1+1$ seedlings were planted in January 1993 .

The Marcola site is located in the western Cascade Mountain foothills east of Springfield on a gentle less than $10 \%$ south-southeast slope elevations ranging from 244 to $274 \mathrm{~m}$. Soils are of the Nekia series and are well-drained and moderately deep, located on foothills and higher rolling uplands. They were formed in colluvium and residuum weathered from basic rock. Site index for Marcola is $37 \mathrm{~m}$ (base age $=50 \mathrm{y}$ ). Rainfall averages $1329 \mathrm{~mm}$ per year. The Marcola site was logged by processor and shovel in 1992 and was scarified and ripped in September that same year. Slash was piled and left on site. Before harvest the stand consisted of 65-y-old Douglas-fir. The site was planted in February 1993 with Douglas-fir $1+1$ seedlings. The perimeters of both sites were fenced to prevent confounding of results from deer damage.

\subsection{Experimental design}

Each site was installed as a completely randomized design with eight treatments replicated three times per site for a total of 24 plots per site. Each treatment plot measured $21.3 \mathrm{~m} \times 21.3 \mathrm{~m}(0.045 \mathrm{ha})$ in which 49 seedlings were planted in a $3.05 \mathrm{~m} \times 3.05 \mathrm{~m}(10 \mathrm{ft} \times 10 \mathrm{ft})$ grid $\left(9.63 \mathrm{~m}^{2}\right)$ surrounded by a similarly spaced buffer strip of two tree rows. The plots were laid out contiguously, where possible, before planting.

\subsection{Treatments}

Eight vegetation-control treatments were designed to provide vegetation-free zones of different types and sizes (Tab. I). The eight treatments consisted of four spot herbicide applications of different areas, an untreated check, a total vegetation control treatment (TVC) equivalent to a $9.63 \mathrm{~m}^{2}$ area of control, and treatments in which either only the herbaceous plant component or only the woody plant component were controlled. Spot herbicide applications were centered on each tree and consisted of square areas of vegetation control $0.375 \mathrm{~m}^{2}$, $1.49 \mathrm{~m}^{2}, 3.35 \mathrm{~m}^{2}$ and $5.95 \mathrm{~m}^{2}$ in area. For all spot treatments, herbaceous treatments were applied within the spots and all woody competition was controlled in the entire plot - thus only herbaceous competitors were present outside the treated areas. Woody vegetation was controlled in these treatments to prevent its rapid invasion from the plot into the spot treatments minimizing effects of herbaceous treatments. This invasion was expected to be especially intense due to the fencing of plots and lack of deer browse.

Herbaceous treatments, which were applied within spot treatment areas as well as being broadcast across entire plots in both TVC and herbaceous-only treatments, were designed to control all herbaceous 
Table I. Specifications for vegetation-control treatments

\begin{tabular}{lc}
\hline $\begin{array}{c}\text { Treatment } \\
\text { (area or type) }\end{array}$ & $\begin{array}{c}\text { Treatment dimension } \\
(\mathrm{m})\end{array}$ \\
\hline $\begin{array}{l}\text { Area of control } \\
\text { No herbicide (check) }\end{array}$ & $0.0 \times 0.0$ \\
$0.38 \mathrm{~m}^{2}$ & $0.6 \times 0.6$ \\
$1.49 \mathrm{~m}^{2}$ & $1.2 \times 1.2$ \\
$3.35 \mathrm{~m}^{2}$ & $1.8 \times 1.8$ \\
$5.95 \mathrm{~m}^{2}$ & $2.4 \times 2.4$ \\
$9.63 \mathrm{~m}^{2}$ (total vegetation control) & $3.1 \times 3.1$ \\
Selective control & \\
Woody vegetation only & $3.1 \times 3.1$ \\
Herbaceous vegetation only & $3.1 \times 3.1$ \\
\hline
\end{tabular}

species present, which required the use of several chemicals. Treatment consisted of hexazinone at $1.68 \mathrm{~kg} \mathrm{ha}^{-1}$ (ai) in year 1 , and both hexazinone at $1.12 \mathrm{~kg} \mathrm{ha}^{-1}$ (ai) and sulfometuron at $0.07 \mathrm{~kg} \mathrm{ha}^{-1}$ (ai) in year 2 . The herbicides were applied from a backpack with a gaspowered boom sprayer. The nozzles on the boom were adjusted for the treatment sizes given in Tab. I. Applications were made in early spring before budbreak in years one and two. Treated areas were maintained throughout the first two growing seasons by periodic directed applications of glyphosate in a $1 \%$ aqueous solution. On all plots except the check and herbaceous-only control, woody vegetation was controlled over the entire area by a directed basal application of $3 \%$ triclopyr in diesel applied prior to bud break in spring.

Hexazinone is a broad-spectrum Triazine herbicide active across both annuals and perennials as well as broad leaves and grasses with both foliar and soil activity [32]. Hexazinone blocks electron transport from QA to QB in thylakoid membranes resulting in inhibition of photosynthesis and oxidation of chloroplast lipids and proteins [32]. Sulfometuron is a broad-spectrum sulfonylurea active against both annual and perennial broad leaf and grass species [32]. Sulfometuron's mode of action involves inhibition of acetolactate synthase (ALS) and disruption of isoleucine, leucine and valine synthesis [32]. Both sulfometuron and especially hexazinone have been shown to result in good to excellent pre-emergent control of numerous woody species [16]. Glyphosate is a non-selective foliar-active herbicide that inhibits 5-enolpyruvylshikimate-3-phosphate catalyzed synthesis of the aromatic amino acids phenylalanine, triptophan and tyrosine [32]. Foliarapplied Glyphosate controls most annual and perennial weed species [32]. Triclopyr is a pyridinecarboxylic acid herbicide effective against numerous tree and shrub species when mixed with oil and applied as a bark treatment [32]. Acid-induced cell wall loosening resulting from stimulation of a membrane-bound ATPase protein pump is thought to be one of triclopyr's primary modes of action [32].

\subsection{Measurements}

Douglas-fir variables measured immediately after planting and after onset of dormancy in years 1 through 5 were stem diameter at $15 \mathrm{~cm}$ aboveground, diameter at breast height (DBH), and total height. In year $8, \mathrm{DBH}$, total height and crown radius were measured. Crown radius was measured as the approximate average distance from tree bole to the drip line at the base of the tree. Height to crown base was also measured but was effectively zero for all trees as of year 8. Eighthyear stem volumes for individual trees were calculated using volume equations derived for second-growth Douglas-fir [2]. These equations use both DBH and height - by year 8 all live trees had achieved breast height. Prior to year 8 some seedling heights were below breast height requiring volume to be calculated using the formula of a cone. Calculated individual-tree volume data prior to year 8 were not included in any statistical analysis in this paper. Year 8 volume-per-hectare means were calculated on a per plot basis by multiplying mean individualtree stem volume by percent survival.

Damage to newly flushing buds was noticed during a visit to the sites in May of 1996. Frost damage assessments were made shortly afterwards on a $0-3$ scale with 0 representing no damage, 1 slight damage to lateral buds, 2 severe damage to lateral buds but no damage to the apical bud, and 3 as damage to both lateral and apical buds. Eighthyear volume was not significantly correlated to frost damage at Summit $(p=0.38)$ but was negatively correlated with frost damage at Marcola $(r=-0.69, p<0.0002)$.

\subsection{Analysis}

Data were separated into two distinct data bases prior to analysis. The "Area-of-Control" database included the four area-of-weed-control treatments plus the check and TVC treatments, while the "Herbaceous/Woody" database included the woody-only control, herbaceous-only control, check and TVC treatments. All analyses were performed independently by site. Analysis of area-of-control data was conducted using both ANOVA and non-linear regression. These methods of analysis provide different perspectives, both of which we felt provided only a partial picture of the results. Analysis of variance provides a useful tool to rank treatments at any given point in time. Regression analysis was used to compare treatments within a given time, namely the most recently collected data, in order to look at the pattern of response rather than the significances between treatment means. The value of regression analysis is that we would expect the response pattern to hold regardless of the sample size of the experiment, whereas the ability to detect differences using ANOVA is dependent on the sample size.

Analysis of variance for the six area-of-control treatments (check, $0.38 \mathrm{~m}^{2}, 1.49 \mathrm{~m}^{2}, 3.35 \mathrm{~m}^{2}, 5.95 \mathrm{~m}^{2}$ and TVC) was made using a oneway treatment structure. The herbaceous/woody treatments were analyzed as a $2 \times 2$ factorial with herbaceous control as one factor and woody control as the other factor using the data base that included woody-only control, herbaceous-only control, check and TVC treatments. The check treatment represented the absence of both herbaceous and woody control, while the TVC treatment served as the combination of both woody and herbaceous control. All ANOVA analyses were conducted on mortality, $\mathrm{DBH}$, height, individual-tree volume, volume per hectare and crown radius. Mortality data was logit-transformed prior to analysis to fulfill model assumptions. Means that are presented have been back-transformed. Means comparisons were made using Fisher's protected least significant difference test.

Eighth-year DBH, height, volume per hectare and crown radius responses to increasing area of weed control were modeled using nonlinear regression. The best model was chosen by examining residuals and adjusted $R^{2}$ values. Several linear and nonlinear model forms were examined with the three-parameter power equation shown below best fitting the data:

$$
Y=Y_{0}+a \times X^{b}
$$

where $Y$ equals the predicted value of volume per hectare, $\mathrm{DBH}$, height, or crown radius, $Y_{0}$ equals the mean parameter value when the area of weed control $=0.0 \mathrm{~m}^{2}, a$ and $b$ are parameters to be estimated, and $X$ is the area of weed control. 
Table II. Analysis of variance statistics for eighth-year individual-tree stem volume, DBH, height, crown radius, logit-transformed mortality and volume per hectare responses to varying areas of weed control.

\begin{tabular}{|c|c|c|c|c|c|c|}
\hline Site & Parameter & $D F$ & Sums of squares & Mean square & $F$ value & $\operatorname{Pr}>F$ \\
\hline \multirow[t]{6}{*}{ Summit } & Individual-tree volume & 5 & $1141 . .0$ & 228.2 & 23.9 & $<0.0001$ \\
\hline & $\mathrm{DBH}$ & 5 & 62.0 & 12.4 & 20.6 & $<0.0001$ \\
\hline & Height & 5 & 101551.1 & 20310.2 & 6.3 & 0.0043 \\
\hline & Crown radius & 5 & 12858.6 & 2571.7 & 14.7 & $<0.0001$ \\
\hline & Mortality & 5 & 1.8 & 0.4 & 2.6 & 0.0779 \\
\hline & Volume $\left(\mathrm{m}^{3} \mathrm{ha}^{-1}\right)$ & 5 & 1252.7 & 250.5 & 20.0 & $<0.0001$ \\
\hline \multirow[t]{6}{*}{ Marcola } & Individual-tree volume & 5 & 246.9 & 49.4 & 4.0 & 0.0229 \\
\hline & $\mathrm{DBH}$ & 5 & 14.0 & 2.8 & 6.5 & 0.0039 \\
\hline & Height & 5 & 67902.6 & 13580.5 & 3.1 & 0.0501 \\
\hline & Crown radius & 5 & 8307.0 & 1661.4 & 4.2 & 0.0200 \\
\hline & Mortality & 5 & 3.1 & 0.6 & 4.0 & 0.0224 \\
\hline & Volume $\left(\mathrm{m}^{3} \mathrm{ha}^{-1}\right)$ & 5 & 292.8 & 58.6 & 4.0 & 0.0228 \\
\hline
\end{tabular}

Table III. Mortality means and differences through year eight for "area of weed control" treatments at Summit and Marcola sites. Means were logit-transformed prior to analysis; back-transformed means are shown.

\begin{tabular}{lcrl}
\hline Site & Area of control $\left(\mathrm{m}^{2}\right)$ & Mortality & \\
\hline Summit & $(\%)$ \\
& 0 (Check) & 14.3 & $\mathrm{a}$ \\
0.375 & 10.7 & $\mathrm{a}$ \\
1.49 & 11.3 & $\mathrm{a}$ \\
& 3.35 & 5.7 & $\mathrm{a}$ \\
& 5.95 & 9.2 & $\mathrm{a}$ \\
& 9.63 (TVC) & 8.2 & $\mathrm{a}$ \\
\hline \multirow{2}{*}{ Marcola } & 0 (Check) & 7.3 & $\mathrm{~b}$ \\
& 0.375 & 19.4 & $\mathrm{a}$ \\
& 1.49 & 9.8 & $\mathrm{~b}$ \\
3.35 & 10.5 & $\mathrm{~b}$ \\
& 5.95 & 7.3 & $\mathrm{~b}$ \\
& 9.63 (TVC) & 6.7 & $\mathrm{~b}$ \\
\hline
\end{tabular}

${ }^{1}$ Means labelled with the same letter are not different at a 0.05 level of significance.

\section{RESULTS}

\subsection{Area of spot weed control}

Area of weed control significantly influenced mortality through year 8 at the Marcola site $(p=0.022)$ but not at the Summit site $(p=0.078)$ (Tab. II). Mortality ranged from 5.7 to $14.3 \%$ for all treatments at Summit, while at Marcola the $0.375 \mathrm{~m}^{2}$ treatment was the only treatment with mortality greater than $10.5 \%(19.4 \%)$, which was significantly higher than every other treatment $(p<0.05)$ (Tab. III). At Summit area of weed control affected both individual-tree volume $(p<$ $0.0001)$ and volume per hectare $(p<0.0001)$ (Tab. II). The two largest area treatments $\left(5.95 \mathrm{~m}^{2}\right.$ and $\left.9.63 \mathrm{~m}^{2}\right)$ resulted in maximal eighth-year individual-tree volume as well as volume per hectare (Fig. 1). Differences in volume growth among treatments are increasing over time. The $5.95 \mathrm{~m}^{2}$ and $9.63 \mathrm{~m}^{2}$ treatments increased eighth-year volume per hectare relative to the check treatment by $286 \%\left(21.9 \mathrm{~m}^{3} \mathrm{ha}^{-1}\right)$ and $333 \%$ $\left(25.5 \mathrm{~m}^{3} \mathrm{ha}^{-1}\right)$, respectively and individual-tree volume relative to the check treatment by $260 \%\left(20.9 \mathrm{dm}^{3}\right)$ and $307 \%$ $\left(24.7 \mathrm{dm}^{3}\right)$, respectively. After three years the $5.95 \mathrm{~m}^{2}$ and $9.63 \mathrm{~m}^{2}$ treatments had increased individual-tree volume relative to the check by only $154 \%\left(0.6 \mathrm{dm}^{3}\right)$ and $199 \%\left(0.5 \mathrm{dm}^{3}\right)$, respectively, and at that time individual-tree volume for the smallest area-of-control treatment $\left(0.375 \mathrm{~m}^{2}\right)$ was not significantly different from the check. Differences in DBH and height among non-check treatments at Summit have expanded little relative to each other through year eight (Fig. 1), but non-check treatments are diverging over time from the check treatment. For example, the two largest treatments $\left(5.95 \mathrm{~m}^{2}\right.$ and $\left.9.63 \mathrm{~m}^{2}\right)$ increased eighth-year DBH by $93 \%(5.0 \mathrm{~cm})$ and $108 \%$ $(5.9 \mathrm{~cm})$, respectively, relative to the check, whereas they increased third-year basal diameter by $61 \%(0.16 \mathrm{~cm})$ and $82 \%$ $(0.21 \mathrm{~cm})$, respectively.

At Marcola all treatments except the smallest area treatment $\left(0.375 \mathrm{~m}^{2}\right)$ had significantly greater eighth-year individual-tree volume than the check treatment, but there were no significant differences among any of the non-check treatments (Tab. II and Fig. 2). However, due to mortality, only the three largest area treatments $\left(3.35 \mathrm{~m}^{2}, 5.95 \mathrm{~m}^{2}\right.$ and $\left.9.63 \mathrm{~m}^{2}\right)$ had significantly greater eighth-year volume per hectare than the check treatment and both the check and $0.375 \mathrm{~m}^{2}$ treatments had significantly less volume per hectare than the two largest area treatments (Tab. II and Fig. 2). Although the absolute difference in individual-tree volume between the check and weed control treatments at Marcola is increasing over time, the difference has 


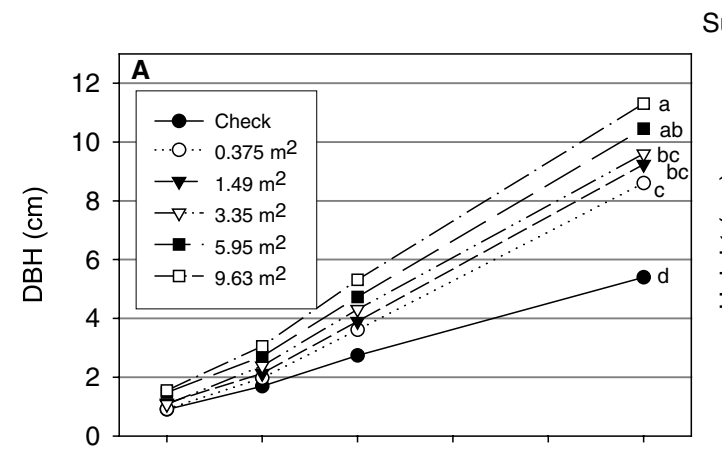

Summit
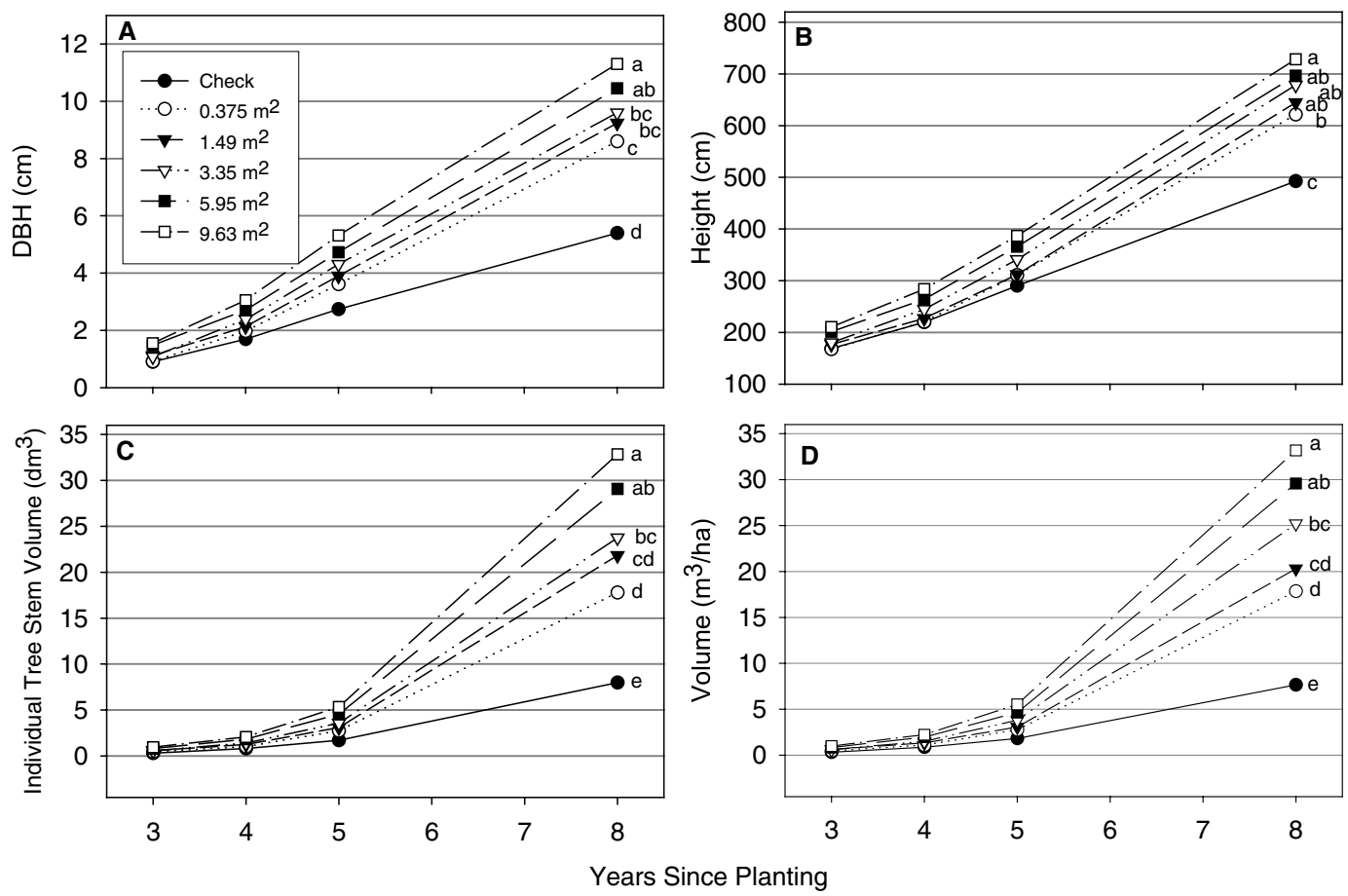

Figure 1. Summit DBH (A), height $(\mathbf{B})$, individual-tree stem volume (C), and stem volume per hectare (D) for the check, $0.375 \mathrm{~m}^{2}, 1.49 \mathrm{~m}^{2}$, $3.35 \mathrm{~m}^{2}, 5.95 \mathrm{~m}^{2}$ and $9.63 \mathrm{~m}^{2}$ (TVC) area-of-control treatments in years 3 through 8 . Means associated with the same letter in year eight are not significantly different $(p<0.05)$.

Marcola
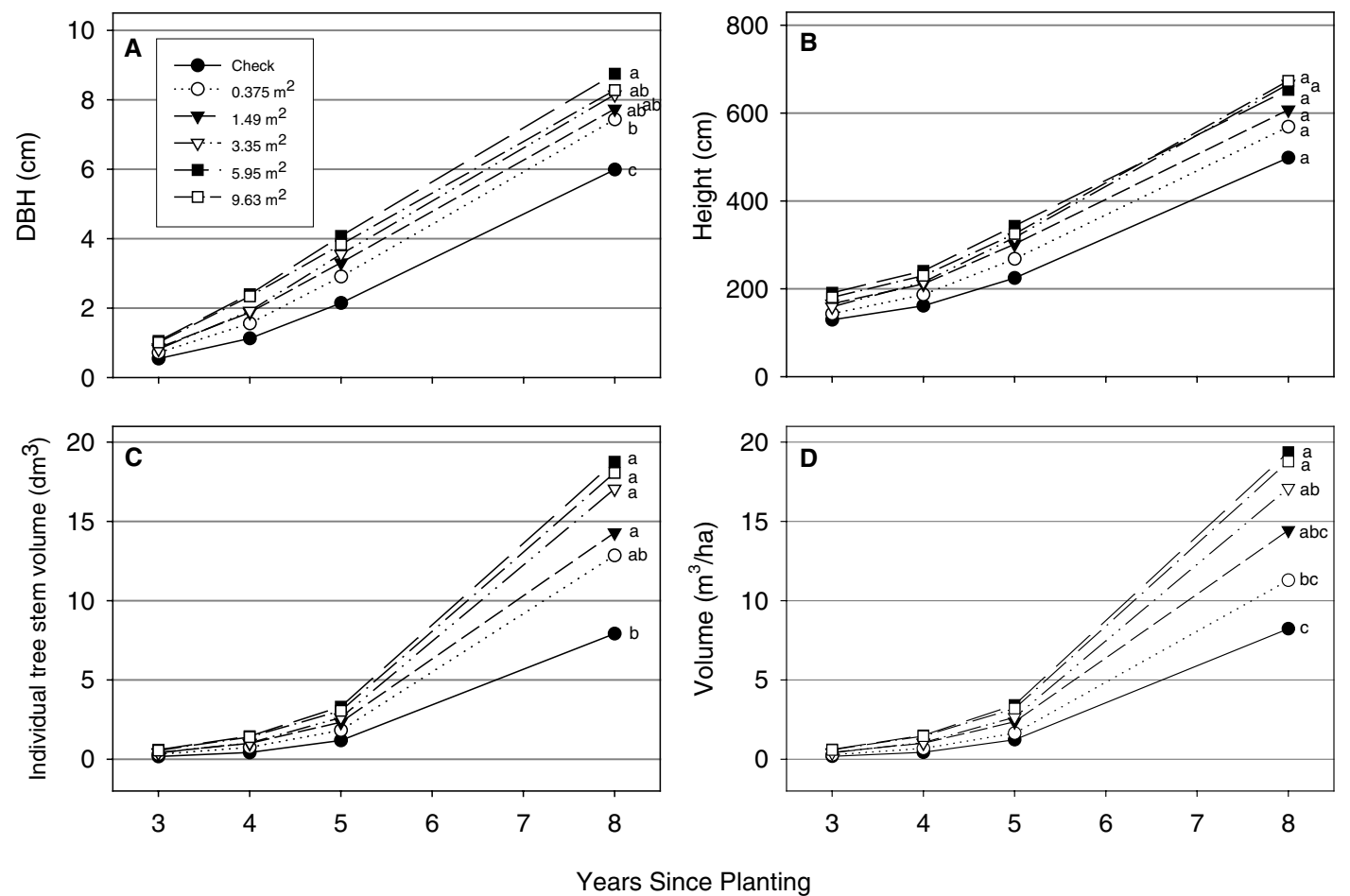

Figure 2. Marcola DBH(A), height $(\mathbf{B})$, individual-tree stem volume (C), and volume per hectare (D) for the check, $0.375 \mathrm{~m}^{2}, 1.49 \mathrm{~m}^{2}$, $3.35 \mathrm{~m}^{2}, 5.95 \mathrm{~m}^{2}$ and $9.63 \mathrm{~m}^{2}$ (TVC) area-ofcontrol treatments in years 3 through 8 . Means associated with the same letter in year 8 are not significantly different $(p<0.05)$. 
Summit
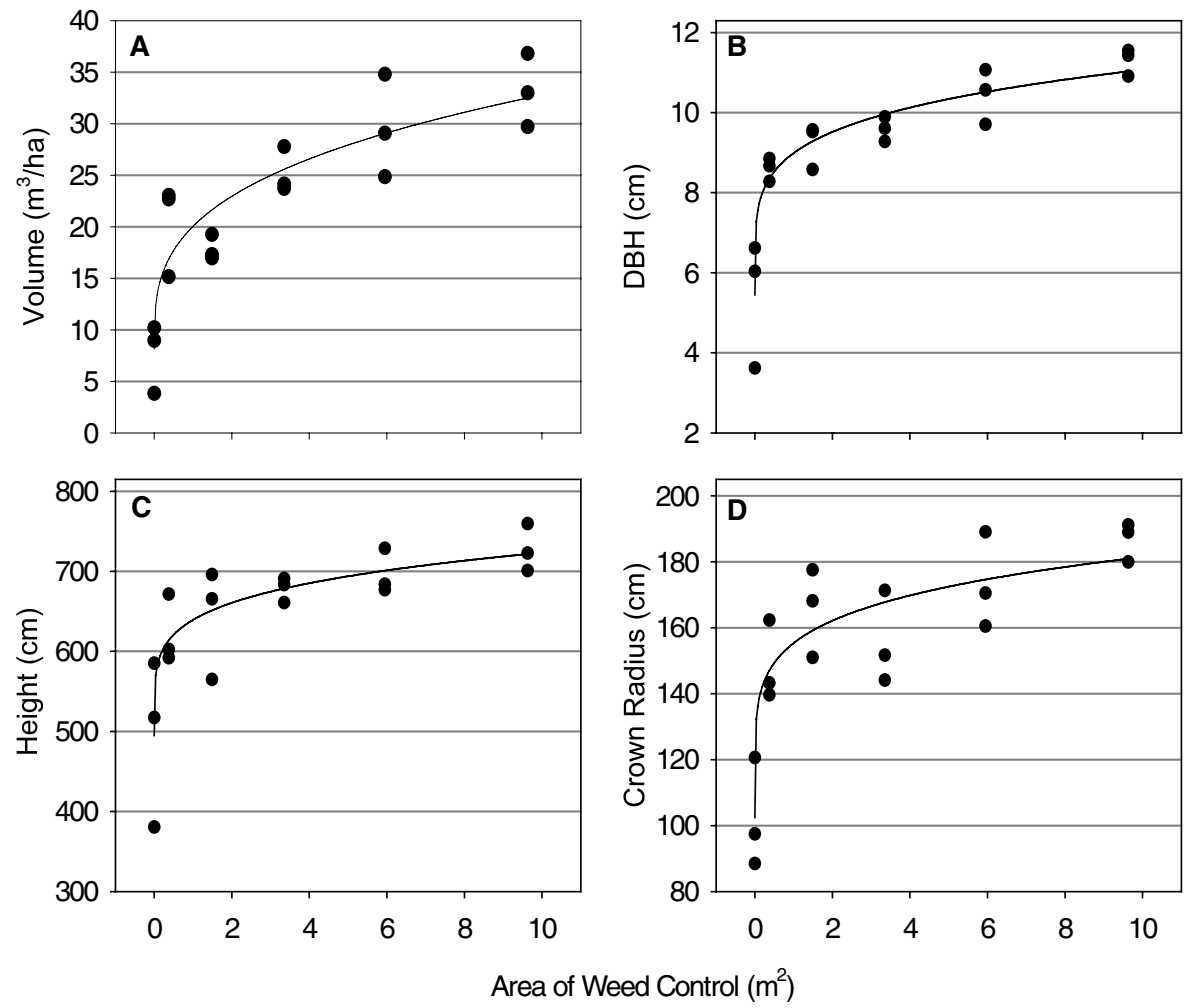

Figure 3. Summit regression lines and plot-mean data points for eighthyear volume per hectare (A), DBH (B), height $(\mathbf{C})$ and crown radius $(\mathbf{D})$ response to area of weed control.

Table IV. Nonlinear regression parameters and statistics for describing eighth-year volume per hectare and individual tree DBH, height, and crown radius at the Summit and Marcola sites as a function of area of weed control using the equation $Y=Y_{0}+a \times X^{b}$.

\begin{tabular}{|c|c|c|c|c|c|c|}
\hline Site & Parameter & $Y_{0}$ & $a$ & $b$ & Adj. $-R^{2}$ & $P$-value \\
\hline \multirow[t]{4}{*}{ Summit } & Volume $\left(\mathrm{m}^{3} \mathrm{ha}^{-1}\right)$ & 8.14 & 11.88 & 0.32 & 0.81 & $<0.0001$ \\
\hline & DBH & 5.45 & 3.54 & 0.20 & 0.87 & $<0.0001$ \\
\hline & Height & 494.87 & 144.40 & 0.20 & 0.68 & $<0.0001$ \\
\hline & Crown radius & 102.40 & 52.91 & 0.17 & 0.79 & $<0.0001$ \\
\hline \multirow[t]{4}{*}{ Marcola } & Volume $\left(\mathrm{m}^{3} \mathrm{ha}^{-1}\right)$ & 8.04 & 5.65 & 0.33 & 0.55 & 0.0010 \\
\hline & $\mathrm{DBH}$ & 5.97 & 1.77 & 0.17 & 0.65 & 0.0002 \\
\hline & Height & 496.40 & 104.90 & 0.25 & 0.48 & 0.0028 \\
\hline & Crown radius & 99.84 & 32.39 & 0.27 & 0.46 & 0.0038 \\
\hline
\end{tabular}

actually diminished as a percentage of the check treatment volume. While the two largest treatments $\left(5.95 \mathrm{~m}^{2}\right.$ and $\left.9.63 \mathrm{~m}^{2}\right)$ increased eighth-year individual-tree volume relative to the check by $139 \%\left(10.9 \mathrm{dm}^{3}\right)$ and $128 \%\left(10.1 \mathrm{dm}^{3}\right)$, respectively, these treatments had increased third-year volume relative to the check by $249 \%\left(0.42 \mathrm{dm}^{3}\right)$ and $226 \%\left(0.38 \mathrm{dm}^{3}\right)$, respectively. Poor DBH growth in the check treatment relative to control treatments has been less pronounced at Marcola compared to Summit and there are no differences among treatments in eighth-year height at Marcola.
Regression analysis was used to further understand the effect of area of control on eighth-year responses. Model fit tended to be better at the Summit site ( $R^{2}$ ranging from 0.68 to 0.87 ) than the Marcola site ( $R^{2}$ ranging from 0.46 to 0.65$)$ due in part to greater variability among plot means at Marcola (Tab. IV). At both sites, the largest gains in growth for all parameters occurred between the check and the $0.375 \mathrm{~m}^{2}$ treatments (Figs. 3 and 4). Tree size increased nearly linearly as area of control increased from $0.375 \mathrm{~m}^{2}$ through $9.63 \mathrm{~m}^{2}$ (TVC). The percentage gain between the $0.375 \mathrm{~m}^{2}$ and TVC treatments was 
Marcola
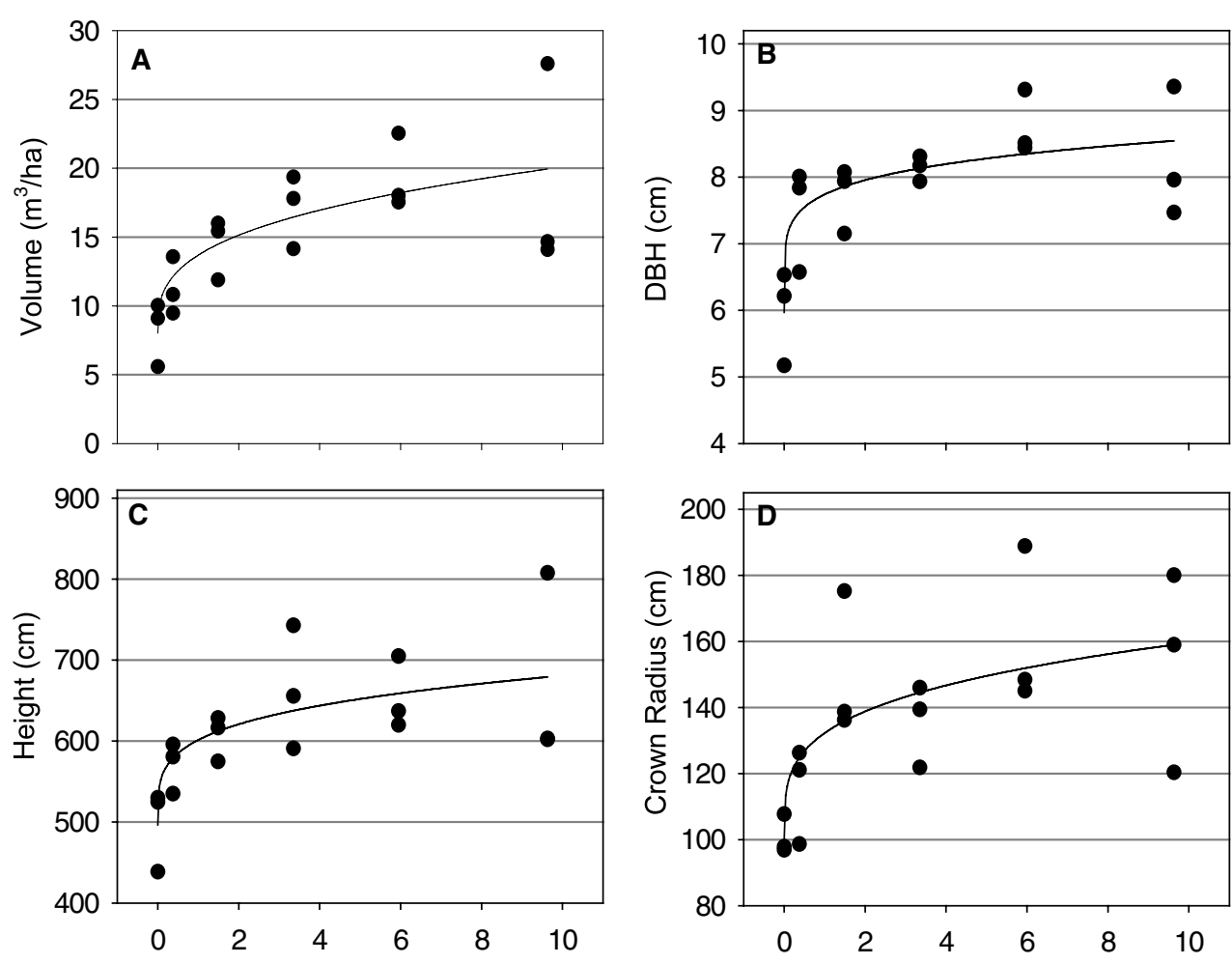

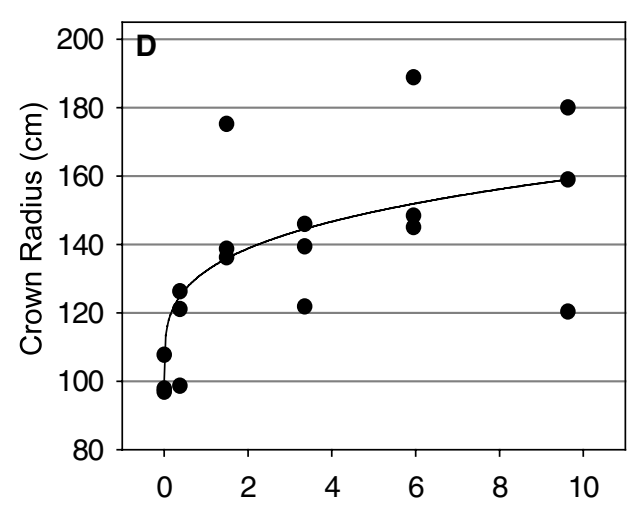

Area of Weed Control $\left(\mathrm{m}^{2}\right)$

Figure 4. Marcola regression lines and plot mean data points for eighthyear volume per hectare (A), DBH (B), height (C) and crown radius (D) response to area of weed control. greater at Summit than Marcola for individual-tree stem volume (85\% and $41 \%$, respectively) and $\mathrm{DBH}(31 \%$ and $17 \%$, respectively) but not for height (17\% and $18 \%$, respectively) or crown radius ( $26 \%$ and $39 \%$, respectively).

\subsection{Herbaceous versus woody control}

At the Summit site both woody-only control and herbaceous-only control increased eighth-year volume (individualtree and on a per-hectare basis), DBH and crown width relative to the check (Tabs. V and VI). Height growth was only increased by herbaceous control. This result represents a major change in the growth response at the Summit site since year three, when woody control had no significant effect on individual-tree volume, DBH, height or crown width [25]. At the Marcola site, on the other hand, herbaceous control improved growth through eight years in all parameters, whereas woody control had no effect on any parameter, the same as was observed after three years. At both sites there were no herbaceous control by woody control treatment interactions for individual-tree volume, volume per hectare, $\mathrm{DBH}$, height or crown width, indicating that herbaceous and woody treatment effects, when present, were additive in nature.

Herbaceous-only control has resulted in greater volume than woody-only control after eight years at both sites (Figs. 5 and 6). Controlling only herbaceous vegetation resulted in similar individual-tree volume gains at both sites $-172 \%\left(13.9 \mathrm{dm}^{3}\right)$ at Summit and $157 \%\left(12.4 \mathrm{dm}^{3}\right)$ at Marcola - while woody- only control at Summit resulted in a gain of $81 \%\left(6.5 \mathrm{dm}^{3}\right)$ compared to a non-significant $17 \%\left(1.4 \mathrm{dm}^{3}\right)$ at Marcola. Largely as a result of the different response to woody control, volume gains have been consistently greater at the Summit site than the Marcola site. Controlling all vegetation at Summit resulted in a $307 \%\left(24.7 \mathrm{dm}^{3}\right)$ individual-tree volume gain, which is considerably more than the gain measured at Marcola for the same treatment, $128 \%\left(10.1 \mathrm{dm}^{3}\right)$. Gains from weed control treatments have diverged since year three at both sites (Figs. 5 and 6 ). This is most obvious for volume but also holds for $\mathrm{DBH}$ and height measures.

Although the interaction between woody and herbaceous control at Summit was not significant, the $307 \%\left(24.7 \mathrm{dm}^{3}\right)$ gain in eighth-year individual-tree stem volume from control of all vegetation appears to be diverging from the sum of gains resulting from herbaceous-only and woody-only treatments $\left(253 \%, 20.4 \mathrm{dm}^{3}\right)$. Data presented by Rose et al. [25] suggested that control of only woody vegetation had released herbaceous vegetation at the Summit site by year 3 .

\section{DISCUSSION}

\subsection{Response to area of weed control}

Our results suggest that complete broadcast weed control increased Douglas-fir growth through year 8 relative to all spot herbicide treatments tested. Although the greatest incremental 
Table V. Analysis of variance statistics for eigth-year individual-tree stem volume, DBH, height, crown radius, mortality and volume per hectare responses to varying levels of herbaceous and woody weed control.

\begin{tabular}{|c|c|c|c|c|c|c|c|c|c|c|}
\hline \multirow[b]{2}{*}{ Parameter } & \multirow[b]{2}{*}{ Effect } & \multirow[b]{2}{*}{$D F$} & \multicolumn{4}{|c|}{ Summit } & \multicolumn{4}{|c|}{ Marcola } \\
\hline & & & $\begin{array}{l}\text { Sum of } \\
\text { squares }\end{array}$ & $\begin{array}{l}\text { Mean } \\
\text { square }\end{array}$ & $F$ value & $\operatorname{Pr}>F$ & $\begin{array}{l}\text { Sum of } \\
\text { squares }\end{array}$ & $\begin{array}{l}\text { Mean } \\
\text { square }\end{array}$ & $F$ value & $\operatorname{Pr}>F$ \\
\hline \multirow{2}{*}{$\begin{array}{l}\text { Individual-tree } \\
\text { volume }\end{array}$} & Woody (W) & 1 & 225 & 225.0 & 15.9 & 0.004 & 0.7 & 0.7 & 0.1 & 0.8300 \\
\hline & $\begin{array}{c}\text { Herbaceous }(\mathrm{H}) \\
\mathrm{W} \times \mathrm{H}\end{array}$ & $\begin{array}{l}1 \\
1\end{array}$ & $\begin{array}{c}774.1 \\
14.2\end{array}$ & $\begin{array}{c}774.1 \\
14.2\end{array}$ & $\begin{array}{c}54.6 \\
1.0\end{array}$ & $\begin{array}{r}<0.0001 \\
0.3469\end{array}$ & $\begin{array}{c}333.6 \\
10\end{array}$ & $\begin{array}{c}333.6 \\
10.0\end{array}$ & $\begin{array}{c}24.0 \\
0.7\end{array}$ & $\begin{array}{l}0.0012 \\
0.4203\end{array}$ \\
\hline \multirow[t]{3}{*}{ DBH } & W & 1 & 14.9 & 14.9 & 13.8 & 0.0060 & 0 & 0.0 & 0.0 & 0.8545 \\
\hline & $\mathrm{H}$ & 1 & 39.8 & 39.8 & 36.7 & 0.0003 & 16.8 & 16.8 & 32.1 & 0.0005 \\
\hline & $\mathrm{W} \times \mathrm{H}$ & 1 & 0 & 0.0 & 0.0 & 0.9776 & 1.1 & 1.1 & 2.1 & 0.1847 \\
\hline \multirow[t]{3}{*}{ Height } & W & 1 & 13179 & 13178.5 & 2.5 & 0.1507 & 987.2 & 987.2 & 0.2 & 0.6503 \\
\hline & $\mathrm{H}$ & 1 & 83847 & 83846.5 & 16.1 & 0.0039 & 72106 & 72106.4 & 16.2 & 0.0038 \\
\hline & $\mathrm{W} \times \mathrm{H}$ & 1 & 3199 & 3198.9 & 0.6 & 0.4562 & 290.9 & 290.9 & 0.1 & 0.8047 \\
\hline \multirow[t]{3}{*}{ Crown radius } & W & 1 & 2982 & 2982.2 & 21.0 & 0.0018 & 5.2 & 5.2 & 0.0 & 0.9350 \\
\hline & $\mathrm{H}$ & 1 & 8425 & 8424.8 & 59.3 & $<0.0001$ & 7801.7 & 7801.7 & 10.6 & 0.0116 \\
\hline & $\mathrm{W} \times \mathrm{H}$ & 1 & 45.7 & 45.7 & 0.3 & 0.5862 & 2280.7 & 2280.7 & 3.1 & 0.1163 \\
\hline \multirow[t]{3}{*}{ Mortality } & W & 1 & 0.029 & 0.029 & 0.09 & 0.7689 & 0.057 & 0.057 & 0.32 & 0.5854 \\
\hline & $\mathrm{H}$ & 1 & 0.820 & 0.820 & 2.60 & 0.1455 & 0.006 & 0.006 & 0.04 & 0.8537 \\
\hline & $\mathrm{W} \times \mathrm{H}$ & 1 & 0.005 & 0.005 & 0.02 & 0.9024 & 0.057 & 0.057 & 0.32 & 0.5854 \\
\hline \multirow[t]{3}{*}{ Volume per hectare } & W & 1 & 235.8 & 235.8 & 11.7 & 0.0090 & 0.2 & 0.2 & 0.0 & 0.9109 \\
\hline & $\mathrm{H}$ & 1 & 830.4 & 830.4 & 41.3 & 0.0002 & 352.0 & 352.0 & 20.3 & 0.0020 \\
\hline & $\mathrm{W} \times \mathrm{H}$ & 1 & 13.7 & 13.7 & 0.7 & 0.4335 & 8.3 & 8.3 & 0.5 & 0.5085 \\
\hline
\end{tabular}

Table VI. Main effect eighth-year individual-tree volume, DBH, height, crown width and volume per hectare means for woody and herbaceous treatments. For the "Woody" main effect "Treated" equals the average of treatments where woody vegetation was controlled (woodyonly and TVC treatments) and "Untreated" equals the average of treatments where woody vegetation was not controlled (herbaceous-only and check treatments). For the "Herbaceous" main effect "Treated" equals the average of treatments where herbaceous vegetation was controlled (herbaceous-only and TVC treatments) and "Untreated" equals the average of treatments where herbaceous vegetation was not controlled (woody-only and check treatments).

\begin{tabular}{|c|c|c|c|c|c|c|c|c|c|}
\hline \multirow[t]{2}{*}{ Parameter } & \multicolumn{2}{|c|}{ Main effect ${ }^{1}$} & \multirow{3}{*}{$\begin{array}{l}\text { Summit } \\
15.0 \\
23.7 * *\end{array}$} & \multirow{3}{*}{$\begin{array}{c}\text { Marcola } \\
14.1 \\
13.6\end{array}$} & \multirow[t]{2}{*}{ Parameter } & \multicolumn{2}{|c|}{ Main effect } & \multirow{3}{*}{$\begin{array}{l}\text { Summit } \\
126.7 \\
158.2 * *\end{array}$} & \multirow{3}{*}{$\begin{array}{l}\text { Marcola } \\
140.1 \\
141.4\end{array}$} \\
\hline & Woody & Untreated & & & & Woody & Untreated & & \\
\hline \multirow{5}{*}{$\begin{array}{l}\text { Individual-tree } \\
\text { volume }\left(\mathrm{dm}^{3}\right)\end{array}$} & & Treated & & & & & Treated & & \\
\hline & & Untreated & 113 & 86 & $\begin{array}{c}\text { Crown Width } \\
(\mathrm{cm})\end{array}$ & Herbaceous & Untreated & 116.0 & 115.3 \\
\hline & Herbaceous & $\begin{array}{l}\text { Untreated } \\
\text { Treated }\end{array}$ & $27.4 * * *$ & $19.1 * *$ & & & Treated & $169.0 * * *$ & $166.3 * *$ \\
\hline & Woody & Untreated & 7.2 & 7.5 & & Woody & Untreated & $11.2 \%$ & $7.9 \%$ \\
\hline & & Treated & $9.5 * *$ & 7.4 & & & Treated & $10.3 \%$ & $7.0 \%$ \\
\hline \multirow[t]{5}{*}{$\mathrm{DBH}(\mathrm{cm})$} & & & & & Mortality & & & & \\
\hline & Herbaceous & Untreated & 6.5 & 6.2 & & Herbaceous & Untreated & $13.5 \%$ & $7.3 \%$ \\
\hline & & Treated & $10.2 * * *$ & $8.6 * * *$ & & & Treated & $8.5 \%$ & $7.6 \%$ \\
\hline & Woody & Untreated & 594.2 & 580.2 & & Woody & Untreated & 14.9 & 14.5 \\
\hline & & Treated & 660.5 & 598.3 & & & Treated & $23.8 * *$ & 14.2 \\
\hline \multirow{2}{*}{ Height $(\mathrm{cm})$} & Herbaceous & Untreated & 543.7 & 511.8 & & Herbaceous & Untreated & 11.0 & 8.9 \\
\hline & & Treated & $710.9 * *$ & $666.8 * *$ & & & Treated & $27.7 * * *$ & $19.8 * *$ \\
\hline
\end{tabular}

\footnotetext{
${ }^{1}$ Within each parameter, effect and site means labelled *, ** or *** are significantly different at $p<0.05, p<0.01$ and $p<0.001$, respectively.
} 
Summit
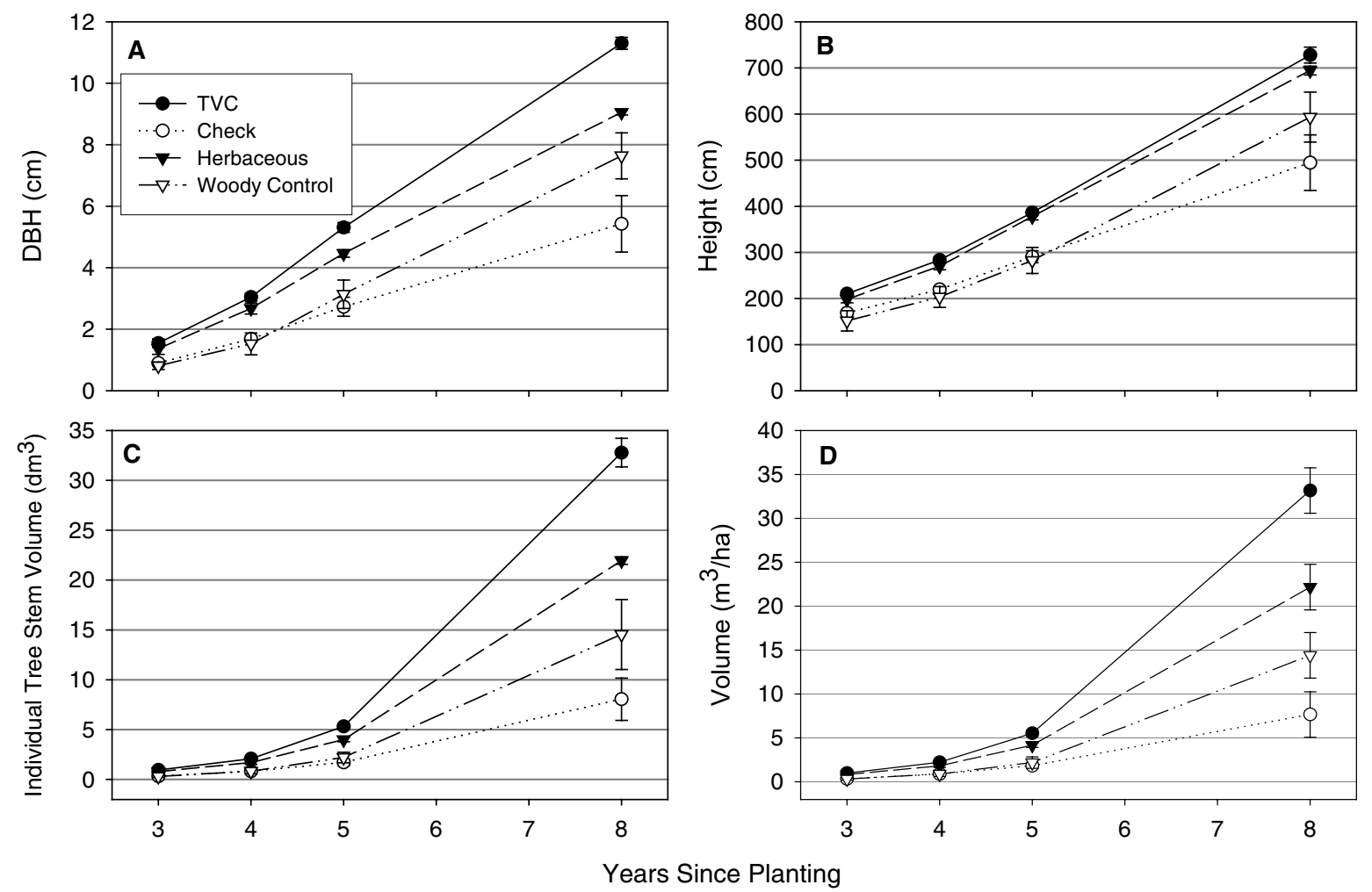

Figure 5. Summit DBH (A), height (B), individual-tree stem volume (C), and volume per hectare (D) response in years 3 through 8 to TVC (total vegetation control), check, woody-only control and herbaceous-only control treatments. Bars represent \pm 1 standard error.

increase in growth in every measured parameter occurred between the check and the smallest area treatment $\left(0.375 \mathrm{~m}^{2}\right)$, volume gains resulting from expanded areas of control were considerable. The largest spot treatment $\left(9.63 \mathrm{~m}^{2}\right)$ improved individual-tree volume growth through eight years relative to the smallest spot treatment $\left(0.375 \mathrm{~m}^{2}\right)$ by $85 \%$ at Summit and $41 \%$ at Marcola. The greater growth response to increased area of weed control at the Summit site may have been related to differences in site quality, species composition or the overall level of competition present at the two sites following the termination of treatments. Total cover in the check treatment after three years at Summit was $149.2 \%$, whereas at Marcola it was $119.2 \%$ [25].

Our data suggest that competitors nearest the seedlings had a disproportionate influence on growth. This follows closely with many competition-modeling approaches that use distance to modify competitive effects $[1,8,23]$. At both sites in this study a larger treatment area was required to maximize DBH growth compared to height growth. These results agree with those of Wagner and Radosevich [29] who found stem diameter to be more sensitive than height to a wide radius $(2.1 \mathrm{~m})$ of competition.

\subsection{Response to herbaceous versus woody competition}

Our results demonstrate that the competitive importance of different plant growth forms changes with time. Through year eight, herbaceous competition had the greatest effect on Douglasfir growth with herbaceous-only control resulting in larger trees than woody-only control at both sites. Woody competition, however, was slow to invade the sites. Summed cover for woody species in the check treatment increased from $7.5 \%$ to $13.4 \%$ to $71.3 \%$ in years one through three of the study at Summit and from $41.7 \%$ to $68.2 \%$ to $119.2 \%$ at Marcola [25]. We suspect that woody species capable of doing so did not start to reach dominance until years 4 to 5 , which is a commonly observed successional trend [10, 26, 27]. A temporal shift in dominance from herbaceous to woody species would explain the observed increase in volume at year 8 resulting from the woody-only control at Summit absent in year 3. Harrington et al. [13] found that across several Washington and Oregon Coast Range plantations that were already two to three years old at the onset of their study, deciduous tree cover did not begin to significantly impact Douglas-fir basal-area and height growth for three years and five years, respectively. By year 10, 


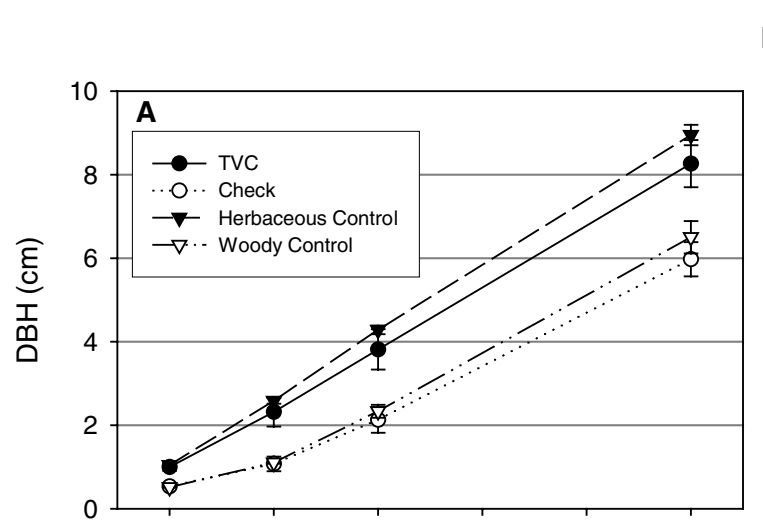

Marcola
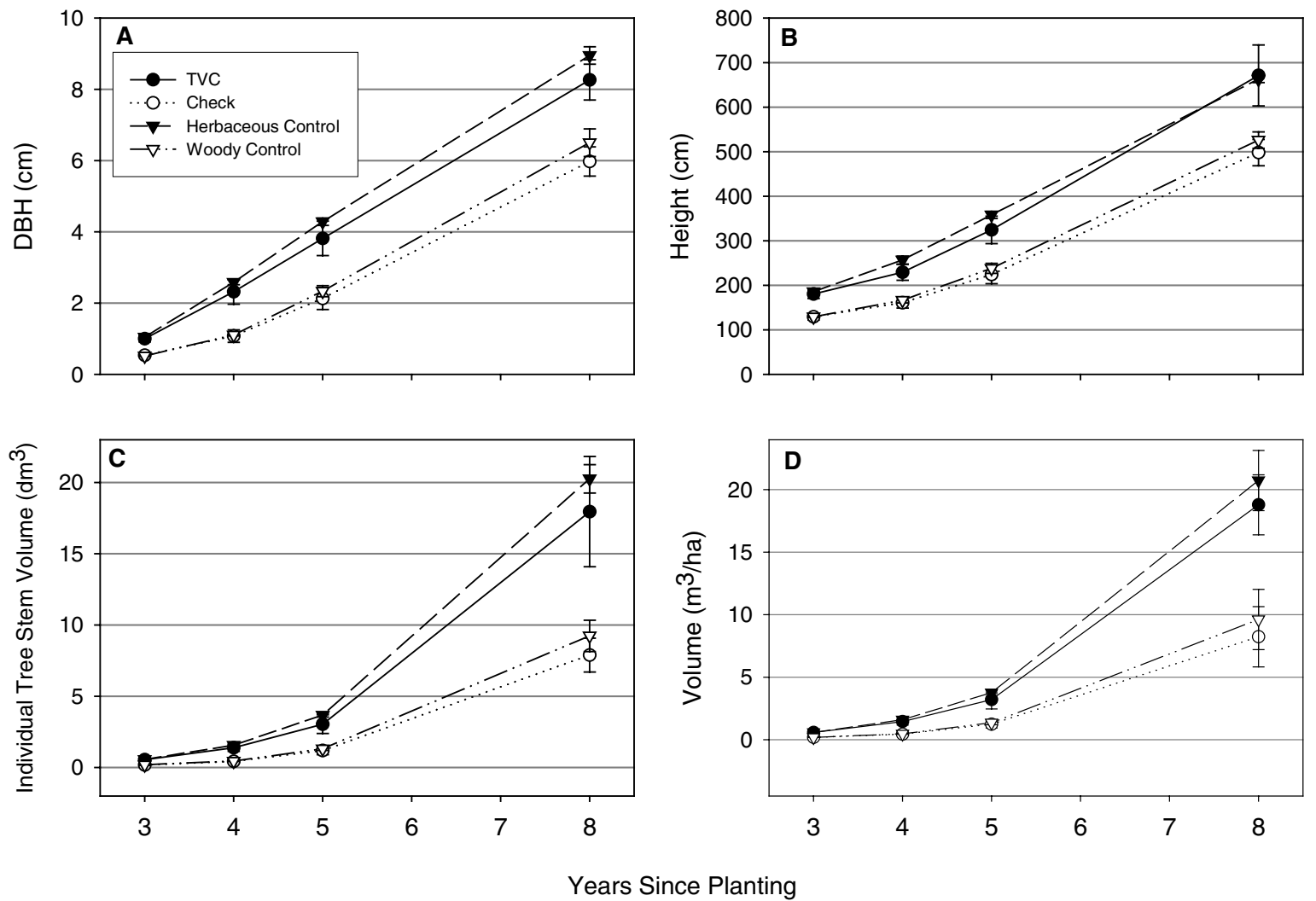

Figure 6. Marcola DBH (A), height (B), individual-tree stem volume (C), and volume per hectare (D) response in years 3 through 8 to TVC (total vegetation control), check, woody-only control and herbaceous-only control treatments. Bars represent \pm 1 standard error.

tree cover was the most competitive component of the vegetation community. Stein [27] examined species composition response to six site preparation treatments across five sites in the Oregon Coast range, and observed a shift from herbaceous species as the dominant component of weed cover years 1 through 3 post-treatment, to increasing woody dominance, primarily red alder (Alnus rubra Bong.), beginning in year 5.

It should be noted that herbaceous-only control reduced third-year summed woody cover relative to the check treatment from $71 \%$ to $63 \%$ at Summit and from $119 \%$ to $62 \%$ at Marcola [25]. This was likely the result of soil active herbicides preventing woody seedling establishment. At both of our sites herbaceous-only control increased Douglas-fir height growth whereas woody-only control did not. This result suggests that height growth was sensitive to below-ground resource competition, which seemingly contradicts the results of Wagner and Radosevich [29], who found that only overtopping woody species whose crowns intermingled with Douglas-fir trees reduced height growth. It may be that increased height growth resulting from herbaceous-only control in our study was related to the reduction in woody competition observed following herbaceous-only treatments.

The eventual impact of woody competitors on our sites varied with the height growth potential of the woody species present. The predominant woody species at Summit was bitter cherry (Prunus emarginata [Dougl. ex Hook] D. Dietr.). Cherry cover ranged from $0.1 \%$ to $13.5 \%$ to $19.8 \%$ to $38.8 \%$ in the TVC, woody-only control, herbaceous-only control and check treatments, respectively, at the end of the third year of the study [25]. Bitter cherry can equal or exceed Douglas-fir height growth rates and potentially overtop or shade Douglasfir seedlings. As a result, control of the woody component for the first three years was necessary to maximize volume growth through year 8 at Summit.

Although normally preferred deer forage, bitter cherry was able to become a significant component of the developing stand at Summit due to the fact that our plots were fenced. Without fencing at this site, response to control of the woody component would have likely been lessened as deer would have reduced the level of cherry in-growth in untreated plots and cover of other potentially dominant tree species was negligible. Bigleaf maple (Acer macrophyllum Pursh) and especially red alder are tree species with widespread occurrence in the Oregon Coast Range with high dominance potential $[6,13,27]$. Had we chosen study sites where either of these species was a significant component of the plant community, response to control of the woody vegetation component would likely have been strong.

In contrast to the Summit site, woody competition at Marcola consisted mostly of species with relatively low height-growth 
potentials - salal (Gaultheria shallon Pursh, bracken fern (Pteridium aquilinum [L.] Kuhn), snowberry (Symphoricarpos albus [L.] Blake) and Rubus L. species - which had little effect on volume growth at Marcola once Douglas-fir saplings had attained dominance. In addition, third year cover of these species, with the exception of salal, was reduced by the herbaceous-only control treatment [25].

Our results are consistent with those of Miller et al. [18] who found that for 15-year-old loblolly pine (Pinus taeda L.) plantations, woody-only control increased pine volume growth relative to an untreated check on sites with high hardwood and high shrub regeneration potential, but had little effect on sites with low hardwood regeneration potential. On sites with high hardwood invasion potential ( $>1800$ hardwood rootstocks/ acre at year one), control of the dominant hardwood competitors - sweetgum (Liquidambar styraciflua L.), water oak (Quercus nigra L.), southern red oak (Quercus falcate Michx.) and blackgum (Nyssa sylvatica Marsh.) - resulted in volume gains that have continually increased in magnitude relative to the check treatment through year 15 [18]. On the other hand, sites with low hardwood invasion potential benefited more from herbaceous-only control.

Control of any one weed component has the potential to release not only crop seedlings but also other weed components present in the community. In our study woody-only control increased herbaceous cover - from $78 \%$ to $101 \%$ at Summit and from $21 \%$ to $56 \%$ at Marcola [25]. This effect may explain the small improvement in growth after woody-only control at Summit and the lack of any improvement at Marcola. Herbaceousonly control also has the potential to release woody vegetation, although this effect was not observed in this study due to the above-mentioned reduction in third-year woody cover associated with soil-active herbicides used for herbaceous-only control. Miller et al. [18] found that herbaceous-only treatments reduced loblolly pine productivity relative to untreated plots on some sites with high hardwood regeneration potentials as a result of released woody competition. In a study on competitive interactions between the shrub whiteleaf manzanita, herbaceous weeds and conifers in mixed Douglas-fir/ponderosa pine stands in southwest Oregon, White and Newton [33] found that control of herbaceous weeds released both manzanita and conifer species.

Many competition models and indices are retrospective analyses. Whereas woody plant cover is likely correlated with past woody cover values, herbaceous cover in year five may be dramatically different from cover in years 1 and $2[5,10,26]$. Our results demonstrate that early differences in herbaceous cover can dramatically impact seedling size through year 8 , with differences that are continuing to expand. This finding supports conclusions by Burton [3] and Wagner and Radosevich [30] that because of their static nature, many competition indices do a poor job of explaining past competitive effects and may not be good predictors of future growth. According to Wagner and Radosevich [30], "Retrospective interpretations of competitive interactions often are limited because there is no direct relationship between current neighborhood conditions and the current size of a target plant. An improved understanding of neighborhood competition can be gained by examining the growth rate of target plants for an extended period of time." It is therefore important to identify the critical periods of com- petition in plantation establishment. Wagner et al. [31] found that control of weeds the first few years immediately after planting had the greatest impact on growth through five years. A study evaluating the critical period of interspecific competition in Pacific Northwest conifer species (including Douglas-fir) is currently underway (Rose and Rosner, unpublished data).

\subsection{Conclusions and implications}

Large areas of tree-centered weed control and control of herbaceous species were the two most important factors in accelerating early growth at both sites studied. Although the greatest incremental increase in growth occurred between the check and the smallest area treatment, large volume gains resulted from expanded areas of control. The impact of woody-only control depended on the presence of woody competitors with significant height growth potential at a given site. At one site with such species present, woody-only control, which appeared to have no effect after three years, improved growth significantly by year 8. The magnitude of treatment effects has also changed in the five years since the first report on this study. This study will continue to be maintained to monitor long-term changes in treatment effects resulting from changing vegetation dynamics and to provide data that can be used to help create realistic growth models for intensively managed stands.

Acknowledgments: The authors gratefully acknowledge the support of the Members of the Vegetation Management Research Cooperative at Oregon State University, Corvallis, Oregon. Great appreciation is also extended to Mr. Scott Ketchum (Forest Capital Partners) who helped with the early measurements and analysis of this study. This study could not have been successfully maintained for such a long time without the enthusiastic support of Weyerhaeusser Co. and Starker Forests Inc.

\section{REFERENCES}

[1] Brand D.G., A competition index for predicting the vigor of planted Douglas-fir in southwestern British Columbia, Can. J. For. Res. 16 (1986) 23-29.

[2] Bruce D., DeMars D.J., Volume equations for second-growth Douglas-fir, USDA For. Serv. Res. Note PNW-239, 1974.

[3] Burton P.J., Some limitations inherent to static indices of plant competition, Can. J. For. Res. 23 (1993) 2141-2152.

[4] Chan S.S., Walstad J.D., Correlations between overtopping vegetation and development of Douglas-fir saplings in the Oregon Coast Range, West. J. Appl. For. 2 (1987) 117-119.

[5] Cholewa A.F., Johnson F.D., Secondary succession in the Pseudotsuga menziesii/Physocarpus malvaceus association, N.W. Sci. 54 (1983) 273-282.

[6] Cole E.C., Newton M., Fifth-year response of Douglas-fir to crowding and nonconiferous competition, Can. J. For. Res. 17 (1987) 181-186.

[7] Daniels R.F., Burkhart H.E., Clason, T.R., A comparison of competition measures for predicting growth of loblolly pine trees, Can. J. For. Res. 16 (1986) 1230-1237

[8] DeLong S.C., The light interception index: a potential tool for assisting in vegetation management decisions, Can. J. For. Res. 21 (1991) 1037-1042.

[9] Dougherty P.M., Lowery R.F., Spot-size of herbaceous control impacts loblolly pine seedling survival and growth, South. J. Appl. For. 15 (1991) 193-1999. 
[10] Dyrness C.T., Early stages of plant succession following logging and burning in the western Cascades of Oregon, Ecology 54 (1973) 57-69.

[11] Hanson T.J., Growth of plantation conifers and whiteleaf manzanita in southwest Oregon, Ph.D. Dissertation, Oregon State Univ., Corvallis, 1997.

[12] Harrington T.B., Tappeiner J.C., Competition affects shoot morphology, growth duration, and relative growth rates of Douglas-fir saplings, Can. J. For. Res. 21 (1991) 474-481.

[13] Harrington T.B., Wagner R.G., Radosevich S.R., Walstad J.D., Interspecific competition and herbicide injury influence 10-year responses of coastal Douglas-fir and associated vegetation to release treatments, For. Ecol. Manage. 76 (1995) 55-67.

[14] Howard K.M., Newton M., Overtopping by successional CoastRange vegetation slows Douglas-fir seedlings, J. For. 82 (1984) 178-180.

[15] Jaramillo A.E., Growth of Douglas-fir in southwestern Oregon after removal of competing vegetation, USDA For. Serv. Res. Note PNW-RN-470, 1988.

[16] Rose R., Ketchum J.S., Effect of several soil active herbicides used in forests of the Pacific Northwest on germination of several common hardwood species, Proc. West. Soc. Weed Sci. 51 (1998) 52-55.

[17] King J.E., Site index curves for Douglas-fir in the Pacific Northwest, Weyerhaeuser Forestry Paper No. 8, Weyerhaeuser Forestry Research Center, Centralia, WA, USA, 1966.

[18] Miller J.H., Zutter B.R., Zedaker S.M., Edwards M.B., Newbold R.A., Growth and yield relative to competition for loblolly pine plantations to midrotation - a southeastern United States regional study, South. J. Appl. For. 27 (2003) 237-251.

[19] Monleon V.J., Newton M., Hooper C., Tappeiner J.C., Ten-year growth response of young Douglas-fir to variable density varnishleaf ceanothus and herb competition, West. J. Appl. For. 14 (1999) 208-213.

[20] Newton M., Preest D.S., Growth and water relations of Douglas-fir (Pseudotsuga menziesii) seedlings under different weed control regimes, Weed Sci. 36 (1988) 653-662.

[21] Oester P.T., Emmingham W., Larson P., Clements S., Performance of ponderosa pine seedlings under 4 herbicide regimes in northeast Oregon, New For. 10 (1995) 123-131.
[22] Petersen T.C., Newton M., Zedaker S.M., Influence of Ceanothus velutinus and associated forbs on the water stress and stemwood production of Douglas-fir, For. Sci. 34 (1988) 333-343.

[23] Richardson B., Davenhill N., Coker G., Ray J., Vanner A., Kimberly M., Optimizing spot weed control: first approximation of the most cost-effective spot size, N. Z. J. For. Sci. 26 (1996) 265-275.

[24] Rose R., Ketchum J.S., Interaction of vegetation control and fertilization on conifer species across the Pacific Northwest, Can. J. For. Res. 32 (2002) 136-152.

[25]Rose R., Ketchum J.S., Hanson D.E., Three-year survival and growth of Douglas-fir seedlings under various vegetation-free regimes, For. Sci. 45 (1999) 117-126.

[26] Schoonmaker P., McKee A., Species composition and diversity during secondary succession of coniferous forests in the western Cascade Mountains of Oregon, For. Sci. 34 (1988) 968-979.

[27] Stein W.I., Ten-year Development of Douglas-fir and associated vegetation after different site preparation on coast range clearcuts, USDA For. Serv. Res. Pap. PNW-RP-473, 1995.

[28] Wagner R.G., Colombo S.J., Regenerating the Canadian Forest, Fitzhenry and Whiteside, Ontario, 2001.

[29] Wagner R.G., Radosevich S.R., Neighborhood predictors of interspecific competition in young Douglas-fir plantations, Can. J. For. Res. 21 (1991) 821-828.

[30] Wagner R.G., Radosevich S.R., Neighborhood approach for quantifying interspecific competition in coastal Oregon forests, Ecol. Appl. 8 (1998) 779-793.

[31]Wagner R.G., Mohammed G.H., Noland T.L., Critical period of interspecific competition for northern conifers associated with herbaceous vegetation, Can. J. For. Res. 29 (1999) 890-897.

[32] Weed Science Society of America, Herbicide Handbook, Ahrens W.H. (Ed.), Weed Science Society of America, Champaign, Illinois, 1994.

[33] White D.E., Newton M., Competitive interactions of whiteleaf manzanita, herbs, Douglas-fir, and ponderosa pine in southwest Oregon, Can. J. For. Res. 19 (1989) 232-238. 